\title{
PERAN SAKSI MAHKOTA DALAM PERKARA PIDANA KORUPSI DI PENGADILAN NEGERI MAKASSAR
}

Muh. Amiruddin

\author{
Universitas Islam Negeri (UIN) Makassar
}

Email: Udinktabrani@yahoo.co.id

\section{Abstract}

The research was carried out in the city of Makassar, Sulawesi Sealatan that is at the State Prosecutor's Office Makassar and Makassar District Court. This study aims to determine the strength of the witness evidence of crown in legislation and to know the implementation of the crown witness in a criminal testimony in the Makassar District Court. The result of the research shows that the strength of Mahkota witness evidence is the same as the witness in general and is in accordance with the applicable law.

Keywords: Mahkota Witness, Corruption

\begin{abstract}
Abstrak
Penelitian dilakasanakan di kota Makassar, Sulawesi Sealatan yaitu pada instansi Kejaksaan Negeri Makassar dan Pengadilan Negeri Makassar. Penelitian ini bertujuan untuk mengetahui kekuatan alat bukti saksi mahkota dalam perundang-undangan dan untuk mengetahui implementasi saksi mahkota dalam kesaksian pidana di Pengadilan Negeri Makassar. Hasil penelitian menunjukkan pada dasarnya kekuatan alat bukti saksi Mahkota sama seperti saksi pada umumnya dan sudah sesuai dengan ketentuan hukum yang berlaku.

Kata kunci : Saksi Mahkota, Korupsi
\end{abstract}




\section{PENDAHULUAN}

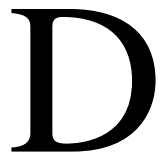

alam kedudukannya sebagai instrumen hukum publik yang mendukung pelaksanaan dan penerapan ketentuan hukum pidana materil, maka Undang - Undang Nomor 8 Tahun 1981 tentang Kitab Undang Undang Hukum Acara Pidana (KUHAP) telah memiliki rumusan sistem pembuktian tersndiri. Adapun rumusan sistem pembuktian tersebut tentunya untuk mendukung tujuan dari hukum acara pidana, yaitu untuk mencari dan memperoleh kebenaran materil. ${ }^{1}$ Dengan tercapainya kebenaran materil maka akan tercapai pula tujuan akhir hukum acara pidana, yaitu untuk mencapai suatu ketertiban, ketentraman, keadilan dan kesejahteraan dalam masyarakat. ${ }^{2}$ Selain itu, untuk mendukung implementasi rumusan sistem pembuktian tersebut tentunya harus berpedoman pada asas-asas yang berlaku dalam proses peradilan pidana, seperti asas praduga tak bersalah (presumtion of inncence), asas peradilan cepat, sederhana dan biaya ringan, asas oportunitas, asas pemeriksaan peradilan terbuka untuk umum, asas persamaan di hadapan hukum (equlity before the law), asas peradilan hukum oleh hakim karena jabatannya dan tepat, asas tersangka atau terdakwa berhak mendapatkan bantuan hukum, asas bahwa tersangka dipandang sebagai pihak atau subjek pada pemeriksaan pendahuluan

dalam arti terbatas (akusator), dan asas pemeriksaan hakim yang langsung dan lisan. ${ }^{3}$ Lebih lanjut dijelaskan bahwa salah satu bentuk dari adanya asas praduga tidak bersalah maka terdakwa sebagai subjek dalam setiap tingkatan pemeriksaan tidak dibebani dengan kewajiban pembuktian. ${ }^{4}$ Hal tersebut merupakan bentuk hak asas terdakwa sebagai konsekuensi dari dianutnya asas pemeriksaan akusator dalam KUHAP. Oleh karena itu, sebagai subjek dalam pemeriksaan maka tersangka atau terdakwa diberikan kebebasan untuk melakukan pembelaan diri terhadap tuduhan atau dakwaan yang ditujukan kepada dirinya. ${ }^{5}$ Ditinjau dari perspektif sistem peradilan pidana maka prihal pembuktian

${ }^{1}$ Departemen Kehakiman RI, Pedoman Pelaksanaan Kitab Undang-Undang Hukum Acara Pidana (Jakarta : Departemen Kehakiman RI, 1982), h. 1.

${ }^{2}$ Andi Hamzah, Hukum Acara Pidana Indonesia (Jakarta : Sinar Grafika, 2001), h. 9.

${ }^{3}$ Syamsul Bahri Radjam, Hak Warga Negara Dalam Hukum Acara Pidana, Panduan Bantuan Hukum : Pedoman Anda Memahami Dan Menyelesaikan Masalah Hukum, ed. A. Patra M. Zein dan Daniel Hutagalung (Jakarta : Yayasan Lembaga Bantuan Hukum Indonesia, 2006), h. 273.

4 M. Yahya Harahap, Pembahasan Permasalahan Dan Penerapan KUHAP : Penyidikan dan Penuntutan (Jakarta : Sinar Grafika, 2003), h.. 41. 107.

\footnotetext{
${ }^{5}$ Darwan Prinst, Hukum Acara Pidana Dalam Praktik (Jakarta : Djambatan, 1998), h.
} 
merupakan hal yang sangat menentukan bagi setiap pihak yang terlibat secara langsung dalam proses pemeriksaan perkara pidana, khususnya dalam hal menilai terbukti atau tidak terbuktinya kesalahan yang didakwakan kepada terdakwa. ${ }^{6}$ Bagi penuntut umum, maka pembuktian merupakan faktor yang sangat penting dalam rangka mendukung tugasnya sebagai pihak yang dibebani untuk membuktikan dakwaannya bahwa terdakwa bersalah melakukan tindak pidana yang didakwakannya. ${ }^{7}$ Berbeda halnya dengan advokat dalam kapasitasnya sebagai penasehat hukum, maka perupakan faktor yang menentukan dalam rangka melakukan pembelaan yang optimal terhadap terdakwa selaku kliennya. Dalam perspektif hukum Islam, orang yang mendakwa hendaklah mengajukan saksi. Maka jika yang mendakwa mempunyai saksi yang cukup, dakwaanya hendaklah diterima oleh hakim. Tetapi jika ia tidak dapat mengemukakan saksi, hakim hendaklah memberikan hak bersumpah kepada terdakwa, dan kalau dia sanggup bersumpah, dia mendapat kemenangan. Tetapi jika terdakwa tidak sanggup bersumpah, yang mendakwa berhak bersumpah, apabila ia bersumpah, ia dianggap menang. Sumpah yang mendakwa ini dalam istilah ahli fiqh dinamakan "sumpah mardud" (sumpah yang dikembalikan). ${ }^{8}$

Dalam kapasitasnya sebagai pihak yang memiliki kewenanagan untuk melakukan pemeriksaan pada tingkat peradilan maka perihal pembuktian merupakan faktor yang sangat menentukan bagi hakim dalam mendukung pembentukan faktor keyakinan hakim. Hal tersebut sebagaimana yang tercantum dalam ketentuan Pasal 183 KUHAP yaitu:

"Hakim tidak boleh menjatuhkan pidana kepada seorang kecuali apabila dengan sekurang-kurangnya dua alat bukti yang sah, ia memperoleh keyakinan bahwa suatu tindak pidana benar-benar terjadi dan bahwa terdakwalah yang bersalah melakukannya."

Jadi menurut pasal 183 KUHAP, hakim dalam menjatuhkan pidana kepada terdakwa harus didasarkan pada minimal dua alat bukti yang sah dan keyakinan hakim yang terbentuk didasarkan pada alat bukti yang sah tersebut. ${ }^{9}$ Oleh karena itu, apabila ditinjau dari perspektif yuridis maka dalam perihal

${ }^{6}$ Lilik Mulyadi, Putusan Hakim Dalam Hukum Acara Pidana : Teori, Praktik, Teknik Penyusunan dan Permasalahannya (Bandung : Citra Aditya Bakti, 2007), h. 49-50.

7 Adami Chazawi, Kemahiran Dan Ketrampilan Praktik Hukum Pidana (Malang : Bayumedia, 2006), h. 201.

${ }^{8}$ Sulaeman Sasjid, Fiqh Islam, (Bandung: Sinar Baru Algensindo, 1998), h. 489.

${ }^{9}$ 0Martiman Prodjohamidjojo, Komentar Atas KUHAP : Kitab Undang-Undang Hukum Acara Pidana (Jakarta : Pradnya Paramita, 1990), h. 133. 
pembuktian tersebut tentunya harus berisi ketentuan tentang jenis alat bukti dan ketentuan tentang tata cara pembuktian yang dilakukan secara benar dan tidak boleh dilakukan secara sewenang-wenang dangan melanggar hak asasi terdakwa

Seringkali dalam berbagai sidang pembuktian perkara pidana, muncul alat bukti yang disebut dengan istilah saksi mahkota. Pada dasarnya, istilah saksi mahkota tidak disebutkan secara tegas dalam KUHAP. Namun dalam kenyataan penggunaan saksi mahkota masih sering kita jumpai dalam persidangan suatu tindak pidana. Penggunaan alat bukti saksi mahkota hanya dapat dilihat dalam perkara pidana yang berbentuk penyertaan, dan terhadap perkara pidana tersebut telah dilakukan pemisahan (splitzing) sejak proses periksaan pendahuluan di tingkat penyidikan. Selain itu, munculnya dan digunakannya saksi mahkota dalam perkara pidana yang dilakukan pemisahan tersebut didasarkan pada alasan karena kurangnya alat bukti yang akan diajukan oleh penuntut umum.Dalam praktiknnya, pengajuan saksi mahkota dalam persidangan bukan hal yang baru. Misalnya, dalam kasus yang menjerat mantan ketua Komisi Pemberantasan Korupsi, Antasari Azhar dalam tindak pidana pembunuhan berencana terhadap Nasrudin. Pada saat itu ketua tim penuntut umum Cirus Sinaga menggunakan alat bukti saksi mahkota Sigit Haryo Wibisono dan Wiliardi Wizard. Kesaksian Sigit Haryo Wibisono dan Wiliardi Wizard dikatakan saksi mahkota di karenakan mereka berdua berstatus terdakwa yang ikut serta dalam melakukan tindak pidana pembunuhan terhadap Nasruddin. ${ }^{10}$ Dalam perkembanganya, ternyata muncul berbagai pendapat, baik yang berasal dari praktisi maupun akademisi, mengenai penggunaan saksi mahkota sebagai alat bukti dalam pemeriksaan perkara pidana. Sebagian pihak berpendapat bahwa penggunaan saksi mahkota dibolehkan karena bertujuan untuk tercapainya rasa keadilan publik. Namun sebagian berpendapat bahwa penggunaan saksi mahkota tidak dibolehkan karena bertentangan dengan hak asasi dan rasa keadilan terdakwa

Hal itu disebabkan oleh karena saksi mahkota adalah berstatus terdakwa, oleh karena itu, sebagai terdakwa maka terdakwa memiliki hak untuk diam atau bahkan hak untuk memberikan jawaban yang bersifat ingkar atau berbohong. Hal ini merupakan konsekuensi yang melekat sebagai akibat dari diwajibkannya terdakwa untuk mengucapkan sumpah dalam memberikan keterangannya.

Selain itu, menurut ketentuan Pasal 66 KUHAP dijelaskan bahwa terdakwa tidak memiliki beban pembuktian. Sebaliknya, dalam terdakwa

\footnotetext{
${ }^{10}$ Hukum Online, "Splitsing Memungkinkan Pelanggaran Hukum," Situs Resmi Hukum Online. http://www.hukumonline.com/berita/baca/lt4b4d61a6cf96f/tuntutan-aa (11 November 2012).
} 
diajukan sebagai saksi mahkota, tentunya terdakwa tidak dapat memberikan keterangan secara bebas karena terdakwa terikat dengan kewajiban memberikan keterangan yang benar diatas sumpah dipersidangan. Konsekuensinya dari adanya pelanggaran terhadap sumpah tersebut maka terdakwa diancam dengan dakwaan baru berupa tindak pidana kesaksiaan palsu sebagaimana yang diatur dalam Pasal 242 KUHPidana.

Adanya keterkaitan dengan sumpah tersebut maka tentunya akan menimbulkan tekanan psikologis bagi terdakwa karena terdakwa tidak dapat lagi menggunakan hak ingkarnya untuk berbohong. Oleh karena itu, pada hakikatnya kesaksiaan yang diberikan oleh saksi mahkota tersebut disamakan dengan pengakuan yang didapat dengan menggunakan kekerasan psikis.

Sedangkan dalam perspektif hukum Islam, menjadi saksi terhadap kerabat, apalagi terhadap ibu bapak, terutama memberikan kesaksian yang akan melibatkan, memberatkan atau seakan mendakwa diri sendiri, adalah suatu perbuatan yang sangat benar. Wajar saja kalau tak banyak orang dapat melakukannya.

\section{PEMBAHASAN}

Dijelaskan di dalam pendahuluan sebelumnya bahwa semenjak Indonesia mengundang-undangkan UU Nomor 8 Tahun 1981 tentang Kitab Undang-Undang Hukum Acara Pidana (KUHAP), maka perihal pembuktian untuk membuktikan kesalahan terdakwa adalah tugas dari Jaksa selaku Penuntut Umum. Hal itu merupakan konsekuensi dari dianutnya azas bahwa tersangka atau terdakwa dipandang sebagai pihak atau subjek pada pemeriksaan pendahuluan dalam arti terbatas (akusator). Namun seringkali dalam berbagai sidang pembuktian perkara pidana, terdakwa dijadikan sebagai saksi dalam perkara-perkara yang berbentuk penyertaan dan diperiksa dengan mekanisme pemisahan berkas perkara (splitzing) seperti yang terdapat dalam Pasal 142 KUHAP, terdakwa yang dijadikan saksi tersebut disebut dengan istilah saksi mahkota.

Istilah saksi mahkota pada dasarnya tidak secara tegas disebutkan dalam KUHAP, namun dalam prakteknya Penuntut Umum seringkali menghadirkan alat bukti saksi mahkota ini dalam persidangan Menurut hasil wawancara dengan Amri Kurniawan, mengatakan bahwa :

"saksi mahkota adalah adanya dua atau lebih terdakwa rnelakukan suatu tindak pidana, dimana berkas perkara masing-masing terdakwa dipisah, dan masing-masing terdakwa menjadi saksi terhadap terdakwa yang lain 
karena kurangnya alat bukti atau yang dikenal dengan istilah saksi mahkota". ${ }^{11}$

Penggunaan saksi mahkota menurut Jaksa Penuntut Umum Amri Kurniawan tidak bertentangan dengan hukum, karena penggunaan saksi mahkota baru dapat dilakukan jika berkas perkara masing-masing terdakwa dipisah, jadi siapapun dapat didengarkan keterangannya sebagai saksi.

Dalam hal Pasal 168 KUHAP yang menyatakan bahwa yang bersamasama sebagai terdakwa tidak dapat didengarkan keterangannya sebagai saksi bilamana berkas perkara masing-masing terdakwa tidak dipisah, namun jika telah mengaiami mekanisme pemisahan (splitzing) penggunaan saksi mahkota dimungkinkan untuk dijadikan sebagai alat bukti karena statusnya tidak dalam hal sebagai terdakwa melainkan telah menjadi saksi.

Lebih lanjut dikatakan bahwa penggunaan saksi mahkota tidak begitu saja dipaksakan oleh Penuntut umum kepada terdakwa. Keterangan saksi mahkota baru mempunyai nilai pembuktian yang sah jika mereka dalam hal ini para terdakwa tidak keberatan untuk diajukan sebagai saksi dan Penuntut Umum rnenyetujuinya. Jika seorang terdakwa bersedia menjadi "saksi mahkota" maka umumnya Penuntut Umum memberikan keringanan tuntutan kepada mereka.

Sedangkan menurut wawancara yang dilakukan dengan Joko Pramudhiyanto, mengatakan bahwa :

"Penggunaan saksi mahkota di persidangan tidak diatur dalarn KUHAP, namun penggunaan alat bukti saksi diatur secara tegas dalam Pasal 185 KUHAP. Namun dalam pemisahan berkas perkara (splitzing) yang terdapat dalam Pasal 142 KUHAP dimungkinkan penggunaan saksi yang berasal dari terdakwa yang dikenal dengan istilah saksi mahkota. Maka pasal 142 KUHAP secara implisit dapat dijadikan dasar hukum penggunaan saksi mahkota"12

Lebih lanjut dijelaskan bahwa Penuntut Umum tidak pernah memaksakan terdakwa untuk mau menjadi saksi dalam persidangan terhadap rekannya sesama terdakwa, tidak menjadi suatu kewajiban menurut KUHAP menjadi "saksi mahkota" tetapi terdakwa berhak menjadi "saksi mahkota" jika ia menginginkannya.

Pada umumnya dalam berbagai kasus terdakwa bersedia menjadi saksi mahkota setelah mendapat penjelasan dari Penuntut Umum. Namun kadangkala

\footnotetext{
${ }^{11}$ Amri Kurniawan, Jaksa Penuntut Umum di Kejaksaan Negeri Makassar, Sulsel, wawancara oleh penulis di Makassar, 3 Desember 2012.

${ }^{12}$ Joko Pramudhiyanto, Jaksa Penuntut Umum di Kejaksaan Negeri Makassar, Sulsel, wawancara oleh penulis di Makassar, 3 Desember 2012.
} 
dalam suatu perkara, terdakwa tidak bersedia menjadi saksi mahkota terhadap sesama terdakwa.

Jika hal itu terjadi maka Penuntut Umum dapat memaksa tersangka untuk menjadi saksi dalam hat ini dikenal sebagai saksi mahkota dan hal itu dimungkinkan dengan catatan berkas perkara masing-masing terdakwa dipisah Untuk dapat memaksa terdakwa bersaksi, Penuntut Umum menggunakan Pasal 159 KUHAP tentang kewajiban untuk menjadi saksi. Dalam hal ini Penuntut Umum mengutamakan tujuan hukum yakni keadilan dan kemanfaatan sebagai prioritas disamping tetap menghormati tujuan hukum yang lainnya yakni kepastian hukum dan dengan tetap memperhatikan hak-hak dari terdakwa.

Namun jika mendengar hasil wawancara dengan Jaksa Joko Pramudhiyanto, maka terdapat inkonsistensi dalam pernyataan Jaksa tersebut, dimana di satu pihak beliau mengatakan tidak memaksa terdakwa untuk mau menjadi "saksi mahkota" terhadap rekannya sesama terdakwa, namun di lain pihak Jaksa tersebut setelah memisah berkas perkara masing-masing terdakwa menurut ketentuan Pasal 142 KUHAP, Jaksa mewajibkan kepada terdakwa untuk menjadi "saksi mahkota" terhadap sesama terdakwa dengan menggunakan Pasal 159 KUHAP karena status terdakwa telah menjadi berubah menjadi saksi melaui proses pemisahan berkas perkara tersebut.

Dalam hukum acara pidana, Jaksa Penuntut Umum berkewajiban untuk membuktikan kebenaran atas jawaban surat dakwaannya. Dengan kata lain yang dibebani pembuktian untuk menyatakan bahwa terdakwa bersalah adalah Penuntut Umum.

Dalam kaitannya dengan penggunaan saksi mahkota sebagai alat bukti adalah dalam beberapa kasus tindak pidana seringkali Penuntut Umum tidak memiliki alat bukti yang cukup. Oleh karena itu Penuntut Umum melakukan pemisahan berkas perkara karena dalam hat itu dimungkinkan dalam Pasal 142 KUHAP, dengan memisah perkara tersebut Penuntut Umum yang sebelumnya kurang memiliki alat bukti dapat menggunakan kesaksian sesama terdakwa untuk menjadi alat bukti saksi dalam persidangan.

Menurut Undang-Undang Nomor 8 Tahun 1981 tentang Kitab Hukum Undang-Undang Hukum Acara Pidana hanya dikenal pengertian saksi sebagaimana dimaksud Pasal 1 angka 26 KUHAP yaitu : "Orang yang dapat memberikan keterangan guna kepentingan penyidikan, penuntutan, dan peradilan tentang suatu perkara pidana yang ia dengar sendiri, ia lihat sendiri, dan ia alami sendiri". 
Dalam perkembangannya menurut ajaran teori dan praktek yang terjadi adalah kita mengenal berbagai bentuk dan macam saksi, seperti:saksi utama, saksi tambahan, saksi ahli, saksi a charge I a de charge, dan saksi mahkota.

Menurut hasil wawancara dengan Pudjo Hunggul Hendrowasisto, mengatakan bahwa dasar hukum saksi mahkota dalam KUHAP tidak dijelaskan secara tegas, namun dalam prakteknya saksi mahkota dapat didefinisikan sebagai berikut :

"Saksi mahkota adalah saksi yang diambil dari salah seorang tersanaka atau terdakwa dalam suatu tindak pidana penyertaan yang berkas perkaranya telah dipisah atau di splits karena kurangnya alat bukti dan kepadanya diberikan "mahkota", dimana mahkota yang dimaksud adalah suatu kehormatan untuk menjadi saksi".

Lebih lanjut dijelaskan bahwa, berdasarkan visi praktik maka dimensi saksi ini memilikidua arti. Pertama, "saksi mahkota" adalah seseorang yang dapat memberikan keterangan guna kepentingan penyidikan, penuntutan dan peradilan tentang suatu perkara pidana yang ia dengar sendiri, ia lihat dan ia alami sendiri (Pasal 1 angka 26 KUHAP). Kedua, "saksi mahkota" diambil dari salah seorang terdakwa yaitu seorang yang karena perbuatan atau keadaannya.

\section{PENUTUP}

Kekuatan alat bukti saksi Mahkota sama seperti saksi pada umumnya, hal ini dapat dilihat dari unsur-unsur saksi dan disini saksi mahkota memenuhi semuanya yakni saksi yang mendengar, melihat dan mengalami langsung peristiwa dan manakala ia berada di bawah sumpah dalam mengungkapkan keterangan dalam persidangan. Jadi disini kekuatan alat bukti saksi mahkota sangat kuat. Apalagi hal itu dimungkinkan oleh KUHP, Yurisprudensi Mahkamah Agung dan dianggap tidak bertentangan dengan hak asasi Terdakwa, dengan catatan Jaksa Penuntut Umum tidak memakasa terdakwa untuk menjadi saksi mahkota di persidangan meskipun berkas perkara diantara masing - masing terdakwa telah dipisah oleh Penuntut Umum, karena jika dipaksakan hal itu bertentangan dengan azas akusator yang dianut oleh sistem hukum acara kita. Implementasi atau penerapan penggunaan saksi mahkota dibenarkan didasarkan pada prinsip-prinsip tertentu yakni dalam perkara delik penyertaan, terdapat kekurangan alat bukti dan diperiksa dengan mekanisme pemisahan berkas perkara. Akan tetapi Implementasi penggunaan saksi mahkota di Pengadilan Negeri Makassar tidak sesuai dengan syarat-syarat penggunaan saksi mahkota. 


\section{DAFTAR PUSTAKA}

Abdoerraef. Al Qura'an dan Ilmu Hukum. Jakarta: Karya Unipress, 1970.

Al, Wisnubroto dan G, Widiartana. Pembaharuan Hukum Acara Pidana. Bandung: Citra Aditya, 2005.

Anwar, Yasmin dan Adang. Sistem peradilan Pidana. Bandung: Widya Padjadjaran, 2011.

Chazawi, Adami. Pelajaran hukum pidanan bagian 3, percobaan dan penyertaan. Jakarta: raja grafindo persada,

---------- Kemahiran Dan Ketrampilan Praktik Hukum Pidana. Malang: Bayumedia, 2006.

Fauzan, Ahmad. Fair Trial : Prinsip-Prinsip Peradilan Yang Adil Dan Tidak Memihak. Jakarta : Yayasan Lembaga Bantuan Hukum Indonesia, 1997.

Hamzah, Andi. Hukum Acara Pidana Indonesia. Jakarta: Sinar Grafika, 2001.

Harahap, M. Yahya. Pembahasan Permasalahan Dan Penerapan KUHAP : Penyidikan dan Penuntutan. Jakarta: Sinar Grafika, 2003.

------------ . Pembahasan Permasalahan Dan Penerapan KUHAP : Pemeriksaan Sidang Pengadilan, Banding, Kasasi Dan Peninjauan Kembali. Jakarta: Sinar Grafika, 2003.

Hukum Online, "Splitsing Memungkinkan Pelanggaran Hukum," Situs Resmi Hukum Online. www.hukumonline.com/Spilitsing (12 Novmber 2012).

Indonesia, Ikatan Hakim. Varia Peradilan No.300, November 2010. Jakarta: IKAHI, 2010.

Kehakiman Republik Indonesia, Departemen. Pedoman Pelaksanaan Kitab Undang-Undang Hukum Acara Pidana. Jakarta, 1982.

Lamintang. Dasar-dasar hukum pidana. Bandung: Sinar baru, 1984.

Loqman, Loebby. Saksi Mahkota "Forum Keadilan”, (Nomor 11, 1995).

Marwan dan Jimmy. Kamus Hukum.Surabaya: Publisher, 2009.

Mulyadi, Lilik. Putusan Hakim Dalam Hukum Acara Pidana : Teori, Praktik, Teknik Penyusunan dan Permasalahannya. Bandung: Citra Aditya Bakti, 2007.

----------.Hukum acara pidana normatif, teoritis, praktik, dan permasalahannya. Bandung: Alumni, 2007.

Muin, Rahayu. Tinjauan Yuridis Terhadap Pemisahan Berkas Perkara Pidana (Splitsing) Oleh Penuntut Umum. Makassar: Skipsi Sarjana, Fakultas Hukum Unhas, 2008. 